\title{
Food loss and waste in food services from educational institutions in Costa Rica
}

\section{Pérdida y desperdicio de alimentos en servicios de alimentación de instituciones educativas de Costa Rica}

\author{
Julián Rojas-Vargas ${ }^{1}$, Yanory Monge-Fernández², \\ María Fernanda Jiménez-Morales ${ }^{3}$, Laura Brenes-Peralta ${ }^{4}$, \\ Manrique Arguedas-Camacho ${ }^{5}$, Cindy Hidalgo-Viquez ${ }^{6}$, \\ Marcela Peña-Vásquez ${ }^{7}$, Blanca Vásquez-Rodríguez ${ }^{8}$
}

Rojas-Vargas, J; Monge-Fernández, Y; Jiménez-Morales, M.F; Brenes-Peralta, L; Arguedas-Camacho, M; Hidalgo-Viquez, C; Peña-Vásquez, M; Vásquez-Rodríguez, B. Food loss and waste in food services from educational institutions in Costa Rica. Tecnología en Marcha. Vol. 34-2. Abril-Junio 2021. Pág

187-196.

Biología Tropical, Máster en Gestión y Estudios Ambientales. Universidad Nacional, Heredia, Costa Rica. Correo electrónico: julian.rojas.vargas@una.cr

iD http://orcid.org/0000-0003-2592-2872

2 Biología Tropical, Bachiller en Biología. Universidad Nacional, Heredia, Costa Rica. Correo electrónico: yanorymf@hotmail.com

iD https://orcid.org/0000-0002-7036-5879

3 Ing. Agropecuaria Administradora, Máster en Ingeniería. Instituto Tecnológico de Costa Rica. Cartago, Costa Rica. Correo electrónico: maría.jimenez@tec.ac.cr (iD) https://orcid.org/0000-0002-9775-2545

4 Ing. Agropecuaria Administradora, Máster en Gerencia y Gestión Ambiental. Instituto Tecnológico de Costa Rica. Cartago Costa Rica. Correo electrónico: labrenes@tec.ac.cr (iD https://orcid.org/0000-0002-5169-9961

5 Administrador de Negocios, Máster en Administración de Negocios. Universidad EARTH, Limón, Costa Rica. Correo electrónico: margueda@earth.ac.cr (iD https://orcid.org/0000-0001-8559-9099

6 Nutricionista, Licenciada en Nutrición. Universidad de Costa Rica, San José, Costa Rica. Correo electrónico: cindy.hidalgoviquez@ucr.ac.cr iD https://orcid.org/0000-0002-0269-5008

7 Nutricionista, Máster en Enfermedades Crónicas no transmisible. Universidad de Costa Rica, San José, Costa Rica. Correo electrónico: marcela.penavasquez@ucr.ac.cr (iD) https://orcid.org/0000-0002-9236-7656

8 Nutricionista, Licda. en Nutrición Humana. Instituto Nacional de Aprendizaje, San José, Costa Rica. Correo electrónico: bvasquezrodriguez@ina.ac.cr 


\title{
Keywords
}

Food loss; food waste; organic waste; university canteen.

\begin{abstract}
One-third of the worldwide food production is lost or wasted, generating impacts in the food systems. However, data indicates that one in nine people suffer from undernourishment or shortage of food in the world. Furthermore, this problem generates adverse impacts in the environment and the economy. Costa Rica is not exempt from this phenomenon; therefore, in compliance with target 12.3 of the Sustainable Development Goals, the country initiated actions through the Costa Rican Food Loss and Waste Reduction Network and one of its members, the Costa Rican Network of Sustainable Educational Institutions (REDIES). This latter committed itself to quantify the food loss and waste (FLW) in the canteens from a pilot group of their members. The objective of this case study was to determine the FLW in the restaurants of five institutions to generate data experience that allows to create indicators and useful information in the search for strategies against food waste. The amount of FLW was measured using the standardized methodology explained in the Guide for this purpose, published by the Costa Rican Network. In general terms, most FLW in this case study comes from the amount of food leftovers. Consequently, it is concluded and recommended to focus on awareness campaigns, quality and portioning to address the issue, and to consider that each institution must place emphasis through its reduction plan with respect to the findings generated in each food service or canteen.
\end{abstract}

\section{Palabras clave}

Pérdida de alimento; desperdicio de alimento; residuo orgánico; restaurante.

\section{Resumen}

Un tercio de la producción global de alimentos es perdida o desperdiciada, generando impactos en los sistemas alimentarios. Sin embargo, los datos indican que, en el mundo, una de cada nueve personas sufre subalimentación o escasez de comida. Además, este problema genera impactos adversos en el ambiente y la economía. Costa Rica no escapa de este fenómeno, por lo que, en concordancia con la meta 12.3 de los Objetivos de Desarrollo Sostenible, se han iniciado acciones a través de la Red Costarricense para Disminución de Pérdida y Desperdicio de Alimentos (Red PDACR) junto a uno de sus miembros, la Red Costarricense de Instituciones Educativas Sostenibles (REDIES). Esta última se comprometió a cuantificar la pérdida y desperdicio de alimentos (PDA) provenientes de los restaurantes de un grupo piloto de cinco de sus miembros. El objetivo del estudio fue determinar las PDA generadas en los restaurantes de esas instituciones para generar experiencia que permitiera crear indicadores e información útil en la búsqueda de estrategias para evitar el desperdicio alimentario. Las PDA fueron cuantificadas empleando la metodología estandarizada que contiene la "Guía para medición de desperdicio de alimentos en cocinas institucionales o comerciales" publicada por la Red PDACR. En general, la mayoría de las PDA detectadas en este caso provienen de alimento dejado en los platos de los usuarios. Consecuentemente, se concluye y recomienda enfocar las intervenciones en campañas de concientización, calidad y porcionamiento, para atender este problema, y considerar a su vez, que cada institución deberá colocar énfasis en un plan de reducción según los hallazgos particulares para cada restaurante. 


\section{Introduction}

It has been estimated that the loss and waste of one-third of the globally produced food, generate significant impacts on the food and nutritional security of people, the economy of the actors of the agri-food system, and the environment [1].

Regarding food security, data from the Food and Agriculture Organization of the United Nations (FAO) show severe problems of malnutrition. On one hand, the high population growth, the high cost to access some foods, and the increase in fast-food restaurants is leading to problems of obesity and poor diet. In contrast, by 2017, one in nine people suffered from undernourishment or shortage of food in the world (approximately 821 million people) [2]. For example, just in the United States of America, food loss represented a $1250 \mathrm{kcal} /$ person/day discard. In addition to this, the economic impact of food loss and waste (FLW) has been estimated at more than 160 billion US dollars in that same country [3]. At the environmental level, it is estimated that the FLW places enormous pressure on natural resources since it amount to annually discarding $250 \mathrm{~km}^{3}$ of water and 4.4 billion tons of $\mathrm{CO}_{2}$ into the atmosphere [4].

There are several concepts to define FLW, whether edible or non-edible portions of food are included. In particular, FAO defines food losses as those agricultural, livestock or fishery products intended for human consumption which are discarded at the field level, in the postharvest, the storage or the transport to distribution centers. On the other hand, food waste is food that was discarded or used in an alternative way from human nutrition, occurred at the distribution and trade process, as well as in the preparation of food and in the final consumption [5]. There is a coincidence in most references such as FAO, the World Resources Institute and the US Department of Agriculture, about the fact that they are products that could be consumed and for various reasons were discarded along the food supply chains [3]; this being the definition adopted in the present study. The foregoing also generates multiple quantification methodologies, such as studies on the generation and composition of waste, self-reporting and diaries, questionnaires, and direct measurements (mass measurement). However, these last processes can be extremely expensive and if geographical coverage is intended, it is challenging to be able to collect statistically representative information. On the contrary, mechanisms such as self-report may contain important biases [6]. Additionally, studies have shown that the causes of FLW are complex and interconnected throughout the chain, where the context plays an important role in the provision of appropriate interventions.

Among the causes of food waste generation, product quality attributed to the intrinsic nature of produce, or related to the market in which it is sold are key triggers of FLW. Inefficiency or failures in the flow of the supply chain, technology, awareness and knowledge (or lack of it), and other behavioral aspects, among others [7] are considered among the causes as well. At the level of food services, food waste monitoring can be seen as an efficiency tool, since the waste generated can be influenced by menu planning, tastes and preferences, employee training, portion size and user acceptance [8].

Several studies have been generated at the consumption level of food supply chains, particularly in food services, in order to start generating data related to the quantity and causes of food waste. A case study in six school canteens in Verona, Italy, determined that there was a $15 \%$ waste of prepared and un-served food [9], while another study in a Portuguese university identified $30 \%$ average waste per plate [8]. On the other hand, a study in a Thai school canteen indicated that only $11 \%$ of the users returned empty plates, while the majority of users (68\%) left between $1 \%$ and $40 \%$ of the served portion [10]. 
In 2015, a new Sustainable Development agenda was created, and its purpose was to create positive transformations in various issues worldwide, through the proposal of several objectives known as the Sustainable Development Goals (SDGs). The objectives and goals set for the year 2030 include in their goal 12.3 of Objective 12, the halving of these food wastes [4].

Costa Rica, being no stranger to this problem, and as a subscriber to the SDGs, promotes the prevention and reduction of FLWs. The Costa Rican Food Loss and Waste Reduction Network was established in 2014 and became a member of the SAVE FOOD @ Global Initiative, in order to generate more awareness among Costa Ricans regarding food waste [11] [12]. Among its many actions, it published the Guide of Food Loss and Waste Measurement in commercial and institutional kitchens in 2017 [12], and the Costa Rican Network of Sustainable Education Institutions-REDIES, as a member of the initiative in the country, acquired the commitment to perform a FLW measurement in the food services belonging to some of its members. By locating only one similar formal study in the country, this research emerged with the main purpose of evidencing through a quantitative approach, data regarding FLW in food services of educational institutions. In addition, this pilot study aids in generating FLW quantification experience in the country. A measurement of the various foods prepared at breakfast and lunch times was carried out, in food services of five institutions.

\section{Methodology}

\section{Location of the study}

The present study was carried out in the food services or canteens of 5 campuses of educational institutions, coded as A, B, C, D and E (one of them partially reported by Rojas-Vargas; Monge-Fernández and Fernández-Hidalgo in 2020) [13]. These belong to tertiary and technical educational institutions, four of them distributed in the Great Metropolitan Area of Costa Rica, and one close to that area towards the Caribbean region. The studied canteens belonged to a mix of main institutional restaurants or satellite canteens, all with a relevant incursion of users according to the institutions. The measurement included the breakfast and lunch times, in three main areas of each canteen (supply and storage area, preparation and waste or leftovers collection area). The daily food production was also quantified to offer further indicators.

\section{Collection and quantification of FLW}

The Guide of Food Loss and Waste Measurement in commercial and institutional kitchens, published by the Costa Rican Network for Food Loss and Waste Reduction, was used [12] [13], taking measurements for at least three days at each site, placing in each restaurant four plastic containers to deposit in them the discarded product, as follows;

- FLWs in the Supply and Storage area, designated as "S"

- FLWs of the preparation area, indicated as "P"

- FLWs caused by leftovers in dishes, designated as "LF"

- Organic waste equivalent to non-edible portions of food, designated as "OW".

All the discarded products from storage shelves, cold rooms, refrigerators, vegetable baskets, cellars and warehouses that could not be used for cooking because they were damaged or expired were placed in the container "S" (Supply and Storage area). It included fruits, vegetables, dairy products, sausages, and preliminary preparations from previous days or hours that were stored, among others. Organic materials coming from the preparation area were placed in container "P", including all foods or portions that were discarded when cooking, 
chopping, cutting, baking, frying or mixing that were burned, damaged, contaminated, dirty or did not meet optimal characteristics to be served and consumed by users. In addition, the waste that occurs when it comes to chopping foods such as meats or foods that cannot be served due to their aesthetics were placed here as well. One last container (OW) was placed to collect non-edible organic waste for that particular fraction [14], such as vegetable peels, eggshells, some seeds, bones, and related food residues that cannot be consumed by people in usual preparations. Finally, all the waste left by the users in their dishes was collected and placed in container "LF". These containers were placed before the start of the breakfast service and until the end of the lunch service, to then be weighed on an electronic scale with the respective tare of the container. Some were weighed until the end of the process; however, non-edible waste containers which usually met their capacity during the day, were weighed throughout the process.

\section{Quantification of daily food production}

Daily food production was accounted throughout the days of sampling in order to be able to subsequently generate an indicator of the FLW regarding the production of the food service, which may be useful as an indicator of efficiency. In this case, the mass of the initial products or foods withdrawn from the storage areas were considered. These data were noted in a template and a conversion factor was applied to raw products to have the value of the finished product [13]. This was done with all foods for both breakfast and lunch. By the end of the process, the weight of the final food that was not served or consumed but that could be stored for later consumption following safety standards was recorded, giving the amount of effective production of the day.

Analysis of the information

Based on the collected data as well as in the local guidelines [12] [13], the following formulas were applied to calculate daily food production (TDP) (formula 1), FLW with respect to daily production (\% FLW DP ) (formula 2) and proportion of FLW on each area, whether it was in the supply and storage area (\% FLW S), preparation (\% FLW P) and plate waste (\% FLW LF) (formulas 3, 4 and 5, respectively).

$$
\begin{gathered}
\text { TDP }=\boldsymbol{S u m}\left(\boldsymbol{W}_{\boldsymbol{i}}-\boldsymbol{W}_{\boldsymbol{f}}\right) \quad(\text { formula } 1) \\
\% \boldsymbol{F} \boldsymbol{L} \boldsymbol{W}_{\boldsymbol{D P}}=\frac{\boldsymbol{F}}{\boldsymbol{D P}} * \mathbf{1 0 0} \quad(\text { formula } 2)
\end{gathered}
$$

Where $W_{\mathrm{i}}=$ Weight of the initial product $(\mathrm{kg}), W_{\mathrm{f}}=$ Weight of the final product $(\mathrm{kg}) . F=F L W /$ day $(\mathrm{kg}), D P=$ Daily production $/$ day $(\mathrm{kg})$

$$
\begin{array}{r}
\% \boldsymbol{F} \boldsymbol{L} \boldsymbol{W}_{\boldsymbol{S}}=\frac{\boldsymbol{C}_{\boldsymbol{S}}}{\boldsymbol{E}} * \mathbf{1 0 0} \quad \text { (formula 3) } \\
\% \boldsymbol{F} \boldsymbol{L} \boldsymbol{W}_{\boldsymbol{P}}=\frac{\boldsymbol{C}_{\boldsymbol{P}}}{\boldsymbol{E}} * \mathbf{1 0 0} \quad \text { (formula 4) } \\
\% \boldsymbol{F} \boldsymbol{L} \boldsymbol{W}_{\boldsymbol{L} \boldsymbol{F}}=\frac{\boldsymbol{C}_{\boldsymbol{L} \boldsymbol{F}}}{\boldsymbol{E}} * \mathbf{1 0 0} \quad \text { (formula 5) }
\end{array}
$$

Where $C_{\mathrm{S}}=$ Waste mass in the supply and storage area, $C P=$ Waste mass in the preparation area, $C_{\mathrm{LF}}=$ Waste mass produced by leftovers in dishes. $E=$ Total sum of FLW per day (mass in $\mathrm{kg}$ of waste in the three areas). 
For the statistical analysis of the data we used the Minitab program Version 18 to examine the average data of the food services of the five institutions. Initially, a data normality analysis was performed, using the Anderson-Darling test, since it tends to be more effective in detecting deviations in the distribution tails [15].

Based on the result of the normality test, and the amount of data (15 total observations in the case of FLW by area of FW generation, five for total daily food production, and five for the sum of total FLW according to the food service by site), the data was treated with non-parametric methods, as these are useful when the assumption of normality is not met and/or the sample size is small [15], as it is in this case. To check if there were significant differences between the groups, the Kruskal-Wallis test was selected, since it uses a logic similar to ANOVA, with the data replaced by categories [16].

\section{Results and Discussion}

As a first step, the average daily production data and of the FLW mass per site considered presented normal data (for an a of $0.05,0.257>0.05$ for daily food production and $0.585>0.05$ for FLW). The Kruskal-Wallis test determined that there were no significant differences between them ( $\mathrm{p} 0.406$ in both cases). Figure 1 shows the food and FLW production data on average per day for each case.

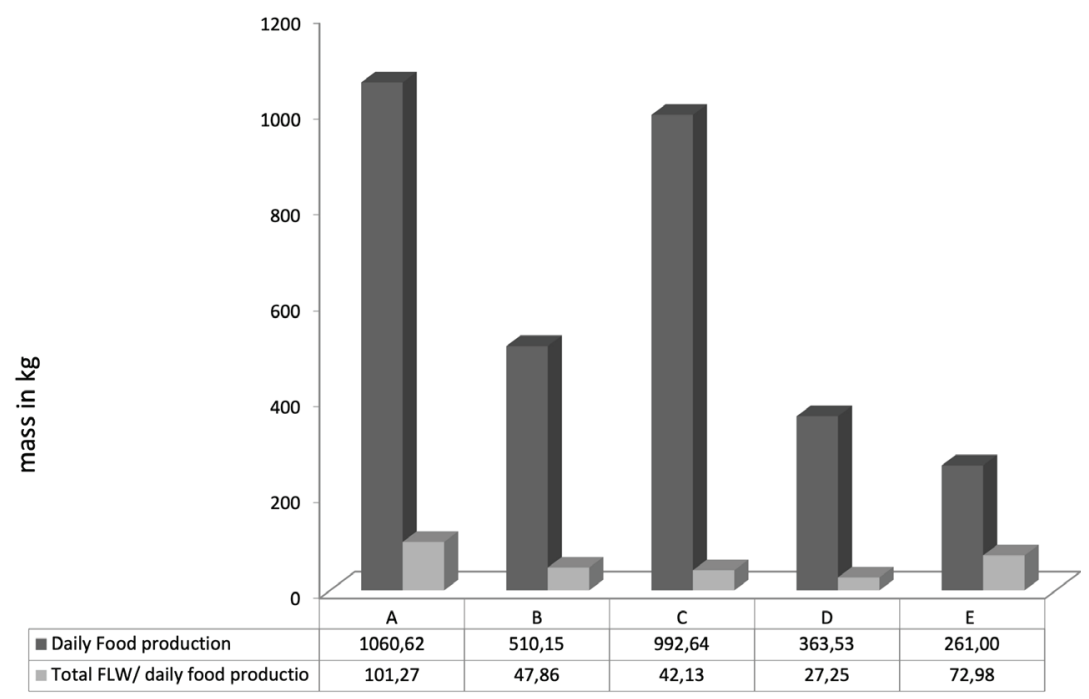

Figure 1. Food production and generation of food waste.

Food production per day and the total FLW generated in each of the institutions, show that institution $A$ is the largest producer of food daily and also of greater mass of FLW, while the one with the lowest daily production turned out to be the second largest generator of FLW. Although it does not represent significant differences, it deserves review to detect best practices between one canteen and another to allow improvements.

The above can be seen more clearly in table 1, where a comparison of the percentage of FLWs regarding to daily production is seen. 
Table 1. Percentage of FLW regarding to daily production and generation of total waste.

\begin{tabular}{|c|c|c|c|c|c|c|}
\hline \multicolumn{7}{|c|}{ Daily food production and total FW evaluated } \\
\hline & A & B & C & D & E & $\begin{array}{c}\text { Simple } \\
\text { Mean }\end{array}$ \\
\hline FW\%/Daily production & 9,55 & 9,38 & 4,24 & 7,50 & 27,96 & 11,30 \\
\hline FW\%/Total waste & 54,61 & 53,01 & 46,64 & 72,53 & 61,93 & 57,44 \\
\hline
\end{tabular}

It is observed that there are no significant differences between the percentage of FLW regarding the daily food production that occurs between the canteens. The relation of the FLW and the food production can constitute an indicator of the efficiency of their operation.

It will be valuable in the future to delve into the practices that occur in each site, looking to achieve indicators less than 5\% of FLW; or seen in another way, those where more than 95\% of food production is being used. On average, these food services have $11.30 \%$ of FLW compared to total daily production. Authors like Ravandi and Jovanovic [17] suggest that depending on the type of food service, FW varies from 36\% to 50\%, therefore the obtained results from these canteens appear to be lower and suggest higher efficiency; and it is similar to the 15\% FW average presented by Falasconi, Vittuari, Politano, \& Segrè, [9].

Further information obtained from table 1 is the proportion of FLW and total organic waste. Institutions commonly dedicate part of their budgets and efforts to properly handle their waste generation, and while general statistics in Costa Rica indicate that almost half of ordinary wastes are composed of biodegradable ones, this table shows that FLW is accountable for over half (57,44\% average, with no significant differences among the sites) of that biodegradable waste. Studies like the one performed by Ahmed, Shanks, Lewis, \& Leitch [18], indicate that prior to interventions in FLW reduction and awareness, this portion represented $61,54 \%$ of the total organic fraction of wastes. The opportunities to reduce general waste generation in educational institutions is relevant then, through proper FLW prevention and reduction interventions. These results are useful indicators in comprehensive waste management strategies based on prevention and reduction from the source of generation, alligned to current national legislation, such as Law 8839 [19]. Likewise, it is possible that the institutions come to consider strategies for the valorization of this type of waste; therefore, the accurate quantification could allow the proper design and sizing of these options. Additionally, if the environmental component is considered within the implications of the FLWs, reducing this percentage would imply an opportunity to minimize greenhouse gases that would result from their conventional degradation in a landfill.

Regarding the analysis of the FLW by area, an analysis of normality considering an a of 0.05 , showed a $\mathrm{p}$ value $=0.027$ so it could be concluded that the data were not normal $(0.027$ $<0.05)$. The Kruskal-Wallis test was applied for the average mass data per area for the study sites, resulting in a $\mathrm{p}$ value of 0.054 , thus providing the conclusion that there were no significant differences between them. The same was done for the FLW per site, resulting in a $p$ value of 0.569 , demonstrating that there were no significant differences in this case either. 


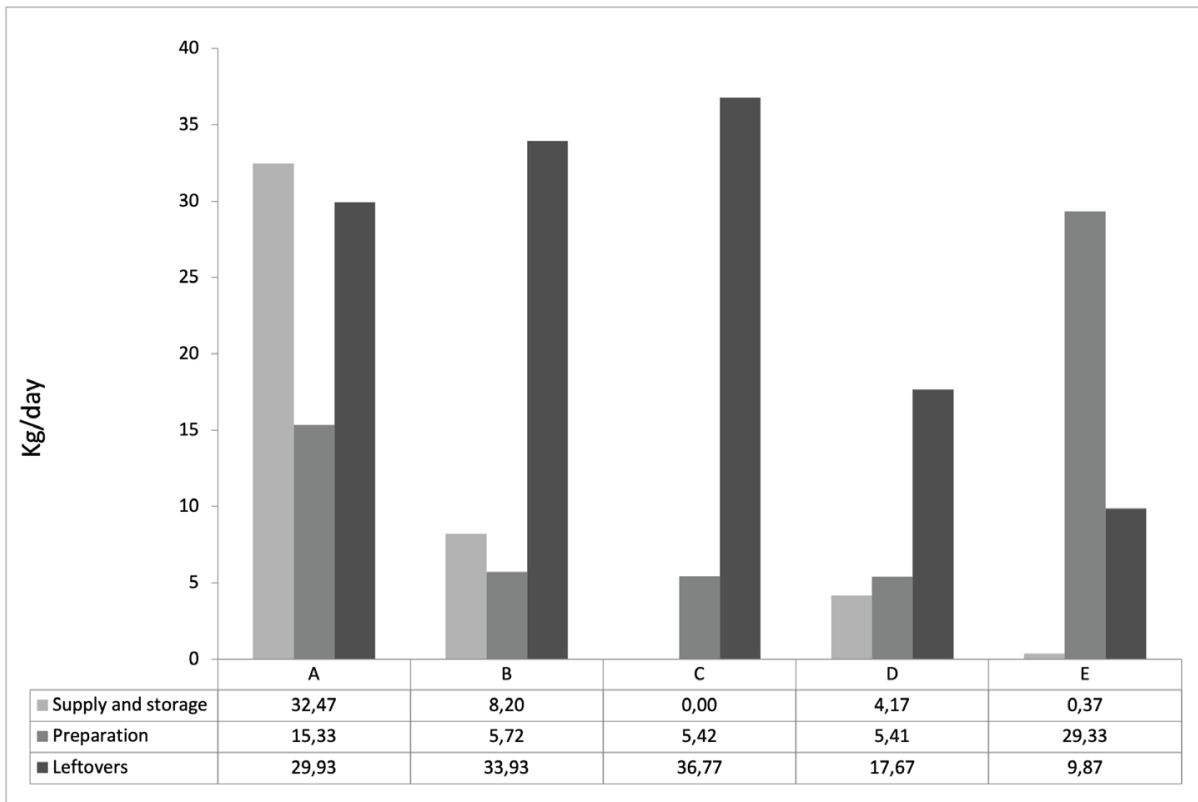

Figure 2. Average mass of FLW generated in each feeding area daily per site.

The result observed in Figure 2 is relevant because it would allow each site to know in which area of its food service it should focus to minimize FLW. It is observed that in three of the sites the largest mass was observed due to leftovers in dishes, while in one of them it was due to the supply and storage area, and another was due to preparation.

In this sense, implementing better controls in the storage of food, using fresh products, and continuously monitoring the expiration and purchase dates would be useful to avoid FLW in the in the supply and storage area; while controls in quality, food handling, control techniques and eventually technology would be appropriate to reduce FLW in preparation. Finally, a review of quality and variety of the menu, temperature, and portioning could affect the case of leftovers as Manomaivibool, Chart-asa, \& Unro [10] and Ferreira, Martins \& Rocha [8] stated in their studies. The truth is that these interventions begin to be possible when priority areas are quantified and identified for each site, which may be further accompanied with more thorough evaluations of causes.

Table 2 shows the average percentage values in the three areas of generation, storage, preparation and waste of dishes according to existing literature and the average obtained in this study (not considering the mass of non-edible parts in the total base of obtained waste).

Table 2. Average FLW in each area evaluated.

\begin{tabular}{|c|c|c|}
\hline Area & Literature (\%) & Average obtained (\%) \\
\hline Supply and Storage & 21 & 19,27 \\
\hline Preparation & 45 & 26,10 \\
\hline Leftovers & 34 & 54,63 \\
\hline
\end{tabular}

The area where the greatest amount of food waste is generated is in the plate residue (54.63\%), which exceeds the value suggested by sources as WRAP [20]. It should be noted that the data presented must be analyzed carefully the particularities of each case must be observed, since the information obtained varies from one institution to another according to the volume, design 
and influx of the service. Although the statistical tests show that there are no differences in the data generated by the institutions, it is necessary to consider that to have greater robustness of the test a larger sample size is required.

In general terms, the area where users must be prioritized and sensitized is the return of dishes, since more than half of the waste is generated in this area. However, the other areas should not be overlooked. Additionally, each institution must focus its reduction plan with respect to the findings generated in each investigation. This is because each institution has restaurants with a number of users and other variables that can behave differently. In one of the sites the priority would be to start evaluating what specific practices or conditions are happening in restaurant kitchens that cause a higher percentage of FW in the preparation area, review food handling practices, control cooking times among other procedures. Others would need to look closer into inventories, and storage practices. Finally, other sites should focus on awareness campaigns against FW and menu quality due to the number of leftovers in the dishes by the users of the restaurants of each institution, as portraited in previous studies by Manomaivibool, Chart-asa, \& Unroj [10]and Ellison, Savchenko, Nikolaus, \& Duf, [21].

\section{Conclusions and recommendations}

This case study represents one of the first executed for Costa Rica where information from various food services is combined in an effort to generate experience in quantification of FLW in this portion of the food supply chains, as well as data that can help to build indicators in the country. Being a case study, there was a limitation of having a reduced data set, which makes it necessary to recommend expanding the sample and days of measurement, in addition to deepen studies that help determine causes of FLW.

Applying the Guide generated by the Costa Rican Network for Food Loss and Waste Reduction to measure the FLW in kitchens, allowed a comparative analysis of the FLW generated in these institutions. This not only supports the importance of having unified quantification methodologies to be able to offer comparisons and inferences, but also opens the possibility for these entities as part of the REDIES consortium, to exchange experiences and achieve best practices that allow the prevention and reduction of FLW.

The systematization of the measurement process, as well as the subsequent monitoring of these cases, will allow the establishment of bases to exemplify success stories that can be replicated in the future in the country and move towards the achievement of SDG target 12.3.

\section{Acknowledgments}

The authors wish to recognize the work of the volunteer students and collaborators of the different institutions of the study who cooperated in data collection processes and previous validation exercises such as the Small Hotels Network (RedNaPH), Nieto, FAO, and the Costa Rican Restaurants Chamber (CACORE). A special mention is given to the professionals and teams that intervened in the planning, execution and reporting processes of these measurement exercises such as students and professionals from the Agribusiness School from TEC, including Marianella Gamboa-Murillo and Andrey Ureña-Jiménez, Andrea Acuña Piedra from GASEL-TEC, Carlos M. Escobedo from EARTH Cafetería and the students from the School of Nutrition Module 3 and FLW internship of years 2018-2019 of UCR. We also thank the General Service Units, Environmental Management Offices and Food Service units for taking these first steps to improve each day their performance, professionalism and commitment to food security and nutrition of thousands of students. 


\section{References}

[1] FAO, Food Wastage Footprint: Full Cost-A ccounting. Final Report., Roma, Italia: FAO, 2014.

[2] FAO, OPS, WFP y UNICEF, "Panorama de la seguridad alimentaria y nutricional en América Latina y el Caribe 2018," 2018. [Online]. Available: http://www.fao.org/3/CA2127ES/CA2127ES.pdf.

[3] K. Kibler, D. Reinhart, C. Hawkins, A. Mohaghegh Motlag and J. Wright, "Food waste and the food-energywater nexus: A review of food waste management alternatives," Waste Management, Volume 74, pp. 52-62 https://doi.org/10.1016/j.wasman.2018.01.014, 2018.

[4] FAO, "FAO and the SDSs. Indicators: Measuring up to the 2030 Agenda for Sustainable Development," 2017. [Online]. Available: http://www.fao.org/3/a-i6919e.pdf

[5] FAO, "Pérdidas y Desperdicios de Alimentos en América Latina y el Caribe.," 2016. [Online]. Available: www. fao.org/publications .

[6] S. Corrado, C. Caldeira, M. Eriksson, O. Jørgen Hanssen, H.-E. Hauser, F. van Holsteijn, G. Liu, K. Östergren, A. Parry and L. Secondi, "Food Waste accounting methodologies: Challenges, opportunities and further advancements," Global Food Security 20, pp. 93-100 https://doi.org/10.1016/j.gfs.2019.01.002, 2019.

[7] M. Canali, P. Amani, L. Aramyan, M. Gheoldus, G. Moates, K. Östergren, K. Silvennoinen, K. Waldron and M. Vittuari, "Food Waste Drivers in Europe, from Identification to Possible Interventions," Sustainability 9, 37, p. doi:10.3390/su9010037, 2017.

[8] M. Ferreira, M. L. Martins and A. Rocha, "Food waste as an index of foodservice quality," British Food Journal Vol. 115 No. 11, pp. 1628-1637 DOI 10.1108/BFJ-03-2012-0051, 2013.

[9] L. Falasconi, M. Vittuari, A. Politano and A. Segrè, "Food Waste in School Catering: An Italian Case Study," Sustainability 7, pp. 14745-14760; doi:10.3390/su71114745, 2015.

[10] P. Manomaivibool, C. Chart-asa and P. Unroj, "Measuring the Impacts of a Save Food Campaign to Reduce Food Waste on Campus in Thailand," Applied Environmental Research 38 (2), pp. 13-22, 2016.

[11] TEC, "RED COSTARRICENSE PARA LA DISMINUCIÓN DE PÉRDIDAS Y DESPERDICIOS DE ALIMENTOS," 2017. [Online]. Available: https://www.tec.ac.cr/red-costarricense-disminucion-perdidas-desperdicios-alimentos.

[12] PDA CR, "Guía para la Medición del Desperdicio de Alimentos en cocinas Institucionales o Comerciales," 2017. [Online]. Available: https://www.tec.ac.cr/sites/default/files/media/doc/2_guia_medicion_cocinas_web. pdf.

[13] Rojas-Vargas, J; Monge-Fernández, Y and Fernández-Hidalgo, K. "Desperdicios de alimentos (DA) en sodas concesionadas de una Universidad Pública en Heredia, Costa Rica". Tecnología en Marcha 33(1), p152-164. https://doi.org/10.18845/tm.v33i1.50291, 2020.

[14] INCAP, "Tabla de composición de Alimentos de Centroamérica, 2da edición. ISBN 999922-880-2-7," 2012. [Online]. Available: http://www.sennutricion.org/media/tablas/INCAP.pdf.

[15] Minitab, "Soporte de Minitab," 9 agosto 2019. [Online]. Available: https://support.minitab.com.

[16] Y. Chan and R. P. Walmslar, "Learning and Understanding the Kruskal-Wallis One-Way Analysis-of Varianceby-Ranks Test for Differences Among Three or More Independent Groups," Physical Therapy, p. 1755, 1997.

[17] B. Ravandi and N. .Jovanovic, "Impact of plate size on food waste : Agent-based simulation of food consumption.," Resources, Conservation \& Recycling, 149, p. 550-565. https://doi.org/10.1016/j.resconrec.2019.05.03, 2020.

[18] S. Ahmed, C. Shanks, M. Lewis and A. Leitch, "Meeting the food waste challenge in higher education challenge," International Journal of Sustainability in Higher Education 19 (6), pp. 1075-1094. https://doi.org/10.1108/ IJSHE-08-2017-0127, 2018.

[19] Sistema Costarricense de información jurídica. Ley no 8839 para la Gestión Integral de Residuos. Online. Available at https://www.pgrweb.go.cr/scij/Busqueda/Normativa/Normas/nrm_texto_completo.aspx?param1= NRTC\&nValor 1=1\&nValor2=68300\&nValor3=83024\&strTipM=TC

[20] WRAP, "Hospitality and Food Service Reducing Food Waste: Starting Off.," WRAP, United Kingdom, 2014.

[21] B. Ellison, O. Savchenko, C. Nikolaus and B. Duf, "Every plate counts : Evaluation of a food waste reduction campaign in a university dining hall," Resources, Conservation \& Recycling, 144(, p. 276-284. https://doi. org/10.1016, 2019. 